\title{
Cola dorrii sp. nov. (Sterculiaceae), a threatened Maputaland Forest endemic of South Africa
}

\author{
Martin Cheek ${ }^{1}$ (D), Poppy Lawrence ${ }^{1}$ \& Warren McCleland ${ }^{2}$
}

Summary. Cola dorrii Cheek sp. nov. is described from Maputaland Sand and Northern Coastal Forest types in KwaZulu-Natal of South Africa. Formerly treated as Cola greenwayi Brenan, it differs in much shorter leaf-blades and petioles, and in the fruitlets which are stipitate, with apices that are rounded and forward-facing. The indumentum has stellate hairs which are soft, with sinuate arms, rather than subscabrid with stiff arms. The species is assessed as Vulnerable using the IUCN 2012 standard due to habitat modification and loss due to humans, elephants and due to the invasive shrub Chromolaena odorata.

Key Words. Conservation, dioecy, elephants, monograph, sand forest.

\section{Introduction}

Cola Schott. \& Endl, was included in tribe Sterculieae of Sterculiaceae sensu lato of the core Malvales for most of the twentieth century. Phylogenetic investigation of Malvales showed that in place of the traditional four families recognised (Malvaceae, Bombacaceae, Sterculiaceae, Tiliaceae) there is a choice of either recognising nine subfamilies in a super-Malvaceae (Bayer et al. 1999; Bayer \& Kubitzki 2003) or recognising the same units as the families, Bombacaceae, Brownlowiaceae, Byttneriaceae, Dombeyaceae, Durionaceae, Helicteraceae Malvaceae sensu stricto, Sparrmanniaceae, Sterculiaceae, and Tiliaceae (Baum et al. 1998; Cheek \& Dorr 2007; Cheek 2007a - j). Cola can therefore now be placed either in MalvaceaeSterculoideae or Sterculiaceae s.s. The second approach is preferred since it is less cumbersome and creates less taxonomic instability (Cheek \& Dorr 2007).

The Sterculiaceae sensu stricto are characterised within Malvales by unisexual flowers with a single perianth whorl which lack an epicalyx. The male flowers have an androgynophore bearing the anthers in a terminal capitulum or ring, the gynoecium vestigial and inconspicuous. Female flowers usually have a sessile or subsessile gynoecium developing into an apocarpous fruit of $(1-) 4-5(-15)$ fruitlets or mericarps, the base surrounded by indehiscent anthers. The family is pantropical, with c. 415 species arranged in 13 genera (Cheek 2007j)

Pterygota Schott \& Endl., a pantropical genus, with dehiscent, woody mericarps containing dry, winged seeds, is in a sister relationship with Cola, while Octolobus Welw., confined to tropical Africa, with numerous spirally inserted indehiscent mericarps, is sister to Pterygota-Cola combined (Wilkie et al. 2006). The remaining genera of the Cola clade, Hildegardia Schott \& Endl., Firmiana Marsili, Pterocymbium R. Br. and Scaphium Schott \& Endl. all have winged fruitlets and are wind-dispersed, and all but the first are confined to SE Asia and adjoining areas. In comparison, the pantropical genus Sterculia L., sometimes confused with Cola, is in an entirely different subclade, and always has dehiscent fruit with the seeds with radicle directed away from the hilum and hard-coated, borne on a placenta with irritant hairs.

The genus Cola with 100 - 125 species of trees and shrubs, the most species-diverse genus in the Sterculiaceae, is characterised by indehiscent (rarely at length dehiscent) mericarps containing seeds with a soft, fleshy seedcoat, the radicle directed towards the hilum. The endocarp is glabrous. Cola is mostly confined to evergreen lowland and submontane forest in continental subsaharan Africa, with only two species in deciduous forest or woodland. While some of the species are widespread, many are extremely local, and some are known from few or single forest patches and so are vulnerable to extinction. Eight species of Cola in Cameroon alone have been assessed as threatened (Onana \& Cheek 2011). Cola nitida (Vent.) Schott. \& Endl. and C. acuminata (P. Beauv.) Schott. \& Endl. are planted throughout the tropics for their seeds which act as stimulants

Accepted for publication 9 May 2018. Published online 2 June 2018

1 Science, Royal Botanic Gardens, Kew, Richmond, Surrey, TW9 3AE, UK. e-mail: m.cheek@kew.org

2 Ecorex, Wierda Park Ext 1, Centurion, Gauteng, South Africa. 
when chewed and are an ingredient of the eponymous and ubiquitous 'Cola' soft drinks. Two other species also have stimulant seeds, but are only locally cultivated (Cheek 2002a; Cheek \& Dorr 2007).

Most species of Cola occur in Tropical Africa, with only two species, C. natalensis Oliv. and C. greenwayi Brenan in South Africa (Verdoorn 1981). In East Africa (Uganda, Kenya and Tanzania), 21 species are native (Cheek \& Dorr 2007). However, West and Central Africa are the heartland of Cola. The largest number for any flora region is that in the Flora of West Tropical Africa (FWTA), with 42 species, and with an additional nine imperfectly-known species (Keay \& Brenan 1958). Thirty-three species are recorded from Gabon (Hallé 1961) and 32 from Congo-Kinshasa (Germain 1963). The Flore du Cameroun account awaits completion. The genus was last monographed by Schumann (1900) when 33 species were recognised. Although Brenan did much research on the genus throughout its range, he confined himself, largely, to publishing accounts of new species (e.g. Brenan \& Keay 1955). This paper renews an attempt to monograph the genus afresh that began 16 years ago (Cheek 2002a, b).

Cola natalensis Oliv. (Oliver 1882) was one of the first described species of the genus, and was until the 1970s the only Cola known from South Africa. It occurs from the eastern Cape to southern Zululand (Palmer \& Pitman 1972). Palmer \& Pitman (1972) seem to be the first to mention a second species of South African Cola which they identified as C. microcarpa Brenan. The earliest herbarium record of this second species so far known dates from 1934 (Forester 52, K, PRE). Palmer \& Pitman (1972) state that this species is fairly common in the short sand forests of Zululand and in the high forest around Lake Sibayi. They give an extensive description and illustrations. In South Africa the species is easily distinguished from C. natalensis even when sterile because the pulvini below the leaf-blades are densely and persistently shortly hairy (not rapidly glabrescent). Locally it is known as the "Hairy Cola" (Moll 1981; Boon 2010).

Drummond in his checklist of Rhodesian woody plants (1975) lists Cola microcarpa as a synonym of C. greenwayi Brenan without comment. This is surprising since Wild (1961) in the Flora Zambesiaca account does not mention C. microcarpa from that region and it may be that Drummond was referring to C. mossambicensis Wild, material of which was once referred to as C. microcarpa, to which it is similar. Coates Palgrave (1977: 598) in Trees of Southern Africa and Verdoorn in her paper 'The genus Cola in southern Africa' (1981) and later authors, follow and support Drummond's synonymy. However in this paper we intend to show that C. microcarpa sensu Palmer \& Pitman (Cola greenwayi sensu Verdoorn pro parte) is a similar but distinct and unnamed species as stated in Cheek \& Dorr (2007: 41), which is described below as Cola dorrii Cheek.

\section{Materials and Methods}

Names of species and authors follow IPNI (continuously updated). Herbarium material was examined with a Leica Wild M8 dissecting binocular microscope fitted with an eyepiece graticule measuring in units of $0.025 \mathrm{~mm}$ at maximum magnification. The drawing was made with the same equipment with a Leica 308700 camera lucida attachment. Specimens were inspected from the following herbaria: BM, $\mathrm{BNRH}, \mathrm{FHO}, \mathrm{K}, \mathrm{NU}$. The format of the description follows those in other papers describing new species in Cola, e.g. Cheek et al. (2002a, b).

All specimens seen are indicated "!" Information on duplicates cited at PRE but not seen derive from the BRAHMS data http://newposa.sanbi.org/sanbi/ Explore. These specimens are included since they occur within the range of Cola dorrii based on specimens seen, and because the only other species of Cola in Natal, C. natalensis, does not overlap in its range with $C$. dorrii. Points were georeferenced using locality information from herbarium specimens. The map was made using ArcMap version 10.5, with additional layers showing protected areas (UNEPWCMC 2017) and lakes (ESRI 1992).

The conservation assessment follows the IUCN (2012) standard. Herbarium codes follow Index Herbariorum (Thiers continuously updated).

Zulu names are standardised according to the current method, which capitalises the first letter.

\section{Results}

Whilst in South Africa only two species of Cola have been recorded (Verdoorn 1981), in the Flora of Tropical East Africa (FTEA) region of Uganda, Kenya and Tanzania, 21 species are found (Cheek \& Dorr 2007). Underpinning that Flora account was Brenan's (1956) account of Cola in Kenya, Uganda and Tanzania, in which both C. greenwayi and C. microcarpa were described for the first time, together with several other new species. The reassessment of East African Cola species for the FTEA account was based on many more specimens than those available to Brenan (1956). However C. greenwayi and C. microcarpa were maintained as they had previously been defined by Brenan (Cheek \& Dorr 2007), and both are separated from $C$. dorrii by numerous characters. The features that separate these three species are set out in Table 1 below.

Vegetatively the "hairy cola" of Kwazulu-Natal is indeed strikingly similar to both Cola microcarpa and C. greenwayi. But since sterile specimens of Cola species 


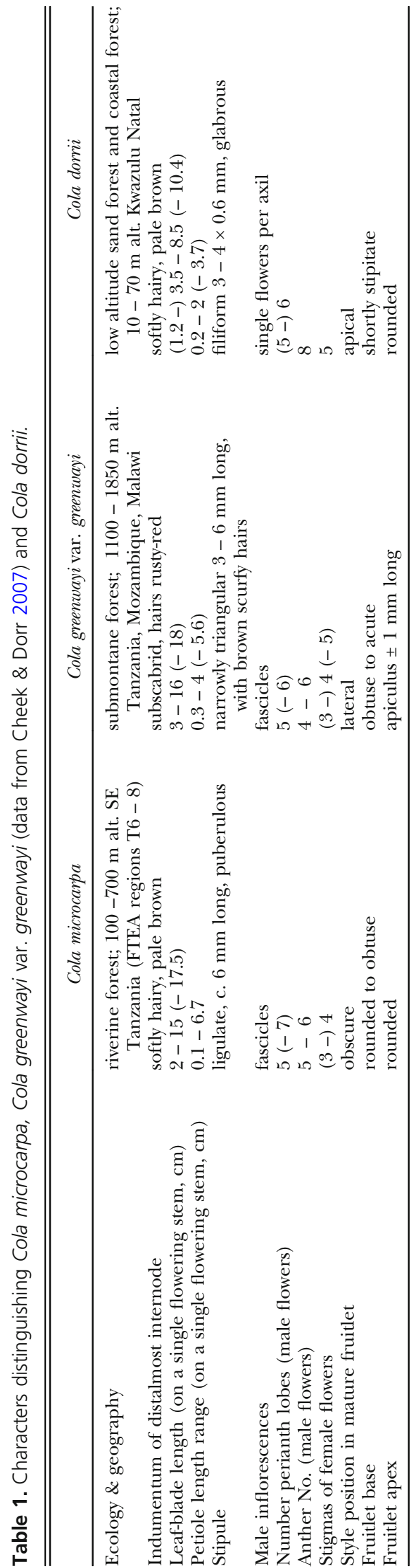

are often impossible to identify to species even by the specialist (Cheek \& Dorr 2007) this is not unusual. However the leaf-blades of the "hairy cola" have a smaller median length than those of $C$. greenwayi (Table 1), and the thickened blade margin is revolute, not flat at the base of the blade. While the young leaves and stem apex of C. greenwayi have dense, rustyred, stiff, subscabrid stellate hairs, those of the "hairy Cola' are sparse, pale brown-pink or translucent and have longer sinuous arms, giving a shaggy appearance. The stipules are dissimilar (Table 1) but since they are caducous, they are or can be, difficult to find.

In flower the 'hairy Cola' produces but a single flower per axil and each male stem has usually $5-6$ (10) flowers of which $1-2$ are at anthesis at any one moment, while in C. greenwayi the male flowers are produced in fascicles and each stem can have many tens to more than 100 flowers.

The tepal indumentum of Cola greenwayi is also characterised by the stiff, rusty-red stellate hairs seen at the stem apex, separating it from the pale brownpink, soft, sinuate hairs of C. dorrii.

While the anther heads of Cola greenwayi have 4-6 anthers, those of $C$. dorrii have 8 . The fruitlets of the two species differ very greatly. Those of $C$. dorrii have a neck or stipe at the base (Fig. 1C; Palmer \& Pitman 1972, as C. microcarpa) and the apex, the stylar area, is rounded, with the styles apical since the fruitlets are erect. In C. greenwayi, as depicted in Wild (1961: tab. $105-5$ ) there is no basal neck (or stipe) and the stylar area is both beaked (rostrate) and lateral.

Cola dorrii Cheek sp. nov. Type: South Africa, "Natal, Ingwavuma distr., near Sihangwane Store, in NewtoniaCleistanthus forest on pallid sands", fr., 25 Jan. 1964, Tinley 883 (holotype K!; isotype NU).

http:/ /www.ipni.org/urn:lsid:ipni.org:names:60476373-2

Cola microcarpa non Brenan, sensu Palmer \& Pitman (1972)

Cola greenwayi var. greenwayi non Brenan, sensu Verdoorn (1981); Moll (1981); Boon (2010), van Wyk \& van Wyk (2013).

Dioecious, evergreen, small tree 3.5 - 8 (-18) m tall, up to $20 \mathrm{~cm}$ diam. at $1.5 \mathrm{~m}$ from ground; bark light-brown, flaking (Palmer \& Pitman 1972); Terminalia-branching; bud-scales c. $10-12$, lanceolate, $3-3.5 \times 1 \mathrm{~mm}$, grey, densely and minutely puberulent. Indumentum dimorphic, stellate, c. $90 \%$ of hairs white, persistent, $0.025-0.03 \mathrm{~mm}$ diam., 7 - 8-armed, arms appressed; c. $10 \%$ of hairs pale brown, caducous, $0.75-1.25 \mathrm{~mm}$ diam., 6 - 9-armed arms erect, sinuate, indumentum covering current season's growth (larger, pale brown hairs falling first) previous season's stems glabrous, 


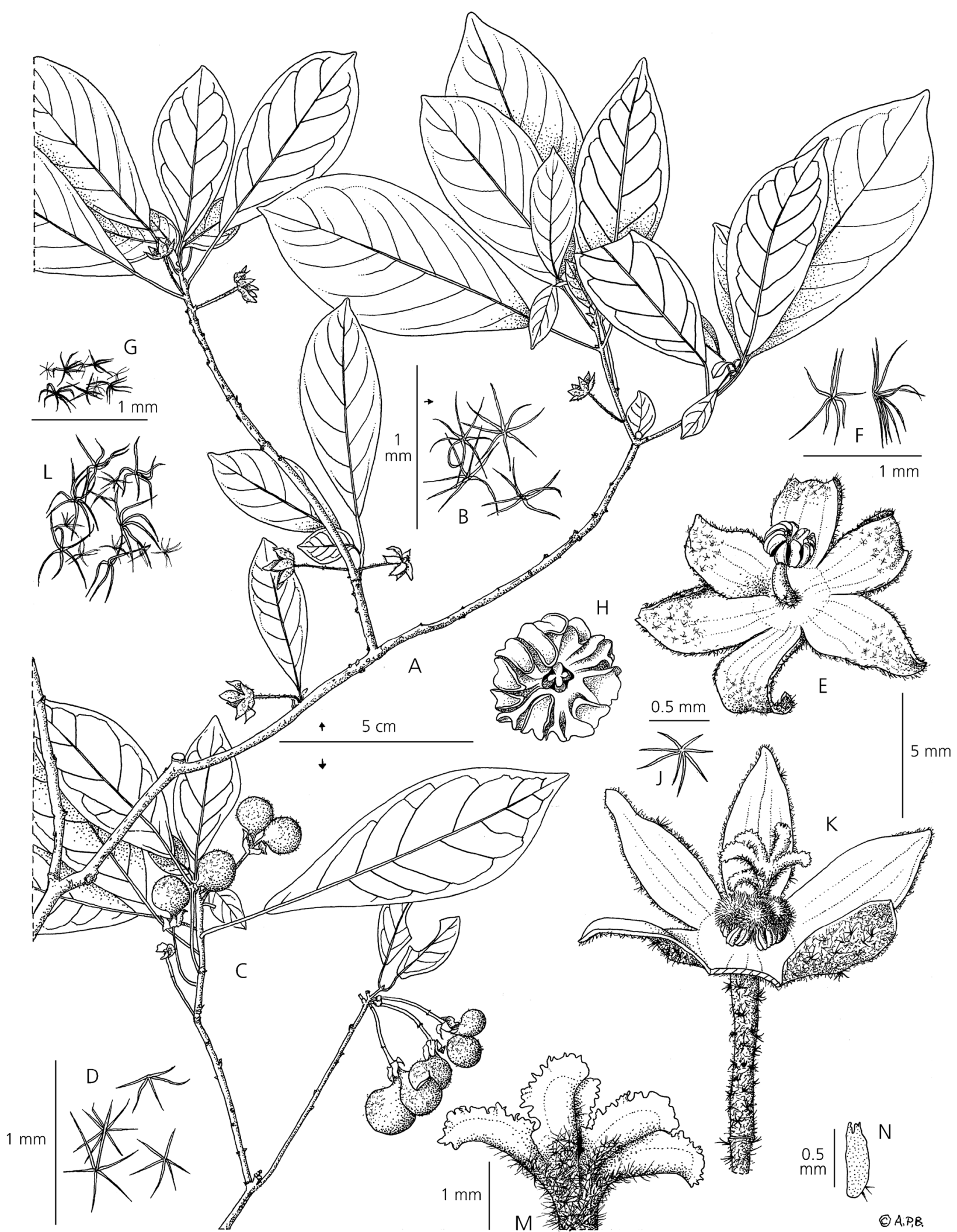

Fig. 1. Cola dorrii. A habit, stem with female flowers; B hairs from young leaf surface from $A$; $C$ habit, stem with fruits; $D$ hairs from surface of fruit; $\mathrm{E}$ male flower; $\mathrm{F}$ hairs from pedicels of male and female flowers; $\mathrm{G}$ dimorphic hairs from exterior sepal surface; $\mathrm{H}$ anther-head, plan view, note vestigial gynoecium; J stellate hair from androgynophore base; $\mathbf{K}$ female flower, one tepal removed; $\mathbf{L}$ external sepal surface female flowers: dimorphic hairs; $M$ stigmas, side view; $N$ stigmatic lobe, transverse section. $A$ \& $B, E, J-M$ from Moll 4388; C from Tinley 883; D, F - H from Pooley 867. DRAWN BY ANDREW BROWN. 
epidermis white, often with deep longitudinal ridges. Leafy stems terete $1.5-2(-3) \mathrm{mm}$ diam., with (2 -) 6 $(-8)$ alternate, spirally arranged leaves (at anthesis) inserted over the distal $1-2 \mathrm{~cm}$ of stem in a rosette, the distalmost leaves subsessile, with the smallest blades, the most proximal leaves with the longest blades and longest petioles. Leaf-blades glossy, dark green, oblanceolate (the smallest elliptic) (1.2 -) $3.5-$ $8.5(-10.4) \times(0.7-) 1.2-3.6(-4.3) \mathrm{cm}$, apex shortly acuminate, acumen as broad as long, c. $0.5 \mathrm{~cm}$ long, base cuneate, abruptly rounded or obtuse, secondary nerves $(4-) 5-9(-11)$ on each side of the midrib, arising at c. $60^{\circ}$ from the midrib, arching gradually up towards the margin and apex, connecting with the secondary nerve above, forming a looping inframarginal nerve $1.5-2 \mathrm{~mm}$ from the margin, domatia absent; tertiary and quaternary nerves inconspicuous; glabrescent, young leaves with dense, overlapping 7 9-armed stellate hairs $0.5-0.7 \mathrm{~mm}$ diam., the arms slender, sinuous. Stipules highly caducous, sub filiform, $3-4 \times 0.6 \mathrm{~mm}$, twisted, subglabrous. Petioles, terete, $2-20 \mathrm{~mm}$ long, $0.5-1 \mathrm{~mm}$ wide pulvinus 3 $6 \mathrm{~mm}$ long, $1 \mathrm{~mm}$ wide, at apex of petiole, persistently densely pale brown hairy; indumentum as stem. Inflorescence buds globose, $1.75-2 \mathrm{~mm}$ diam., 1 (2) per axil at (usually) leafy nodes, flower single, enclosed in c. 6 variously-shaped bracts; proximal bract pair semi-circular, about $5 \times$ broader than long, c. $0.2 \times 1 \mathrm{~mm}$; middle bract pair concave, bifurcate, $2-$ $3 \times$ broader than long, c. $0.5 \times 1.5 \mathrm{~mm}$, persistent postanthesis and becoming flat, exposing the glabrous glossy mid brown adaxial surface; distal bract pair caducous, naviculate, about $3 \times$ longer than broad, constricted midlength, c. $1.75-3 \times 0.8-1.5 \mathrm{~mm}$, outer surface of bracts densely and minutely dull brown puberulent. Inflorescences 1-flowered, bracts caducous or nil, in axils of the previous season's leaves (borne immediately below the leaves, $1-4$ per leafy stem; pedicels $1-1.5 \mathrm{~mm}$ long. Flowers pale green, divided into lobes for $5 / 6$ their radius. Male flowers $12-$ $14 \mathrm{~mm}$ across, pedicels $10-15 \times 0.1 \mathrm{~mm}$, terete, c. $50 \%$ covered by $4-8$-armed stellate hairs, arms $0.2-$ $0.5 \mathrm{~mm}$ long, articulated $7-8 \mathrm{~mm}$ below the flower. Tepals 6 patent (to slightly campanulate); oblanceolate to lanceolate $5.5 \times 2.2 \mathrm{~mm}$; apex acute, abruptly rounded, base $1-1.5 \mathrm{~mm}$ wide, inner surface glabrous in proximal two-thirds, distal third with $30-50 \%$ cover of 3 - 5-armed stellate hairs $0.2-0.35 \mathrm{~mm}$ diam.; outer surface moderately densely stellate-hairy, hairs overlapping, dimorphic, smaller hairs 5 - 10-armed, $0.1-0.15 \mathrm{~mm}$ diam., larger hairs 6 - 8-armed, 0.25 $0.35 \mathrm{~mm}$ diam. Androphore $2 \times 0.5 \mathrm{~mm}$, base densely stellate hairy, hairs c. 8-armed, $0.6 \mathrm{~mm}$ diam., otherwise glabrous. Staminal head c. $2 \mathrm{~mm}$ diam., $1 \mathrm{~mm}$ long, stamens c. 8; gynoecium vestigial, concealed within apex, styles 4 . Female flowers 13 - $14 \mathrm{~mm}$ diam. with pedicels $10-12 \mathrm{~mm}$ long at anthesis, indumentum as male. Tepals 6, patent to ascending, lanceolate, $7.5-8 \times 2.5-3 \mathrm{~mm}$, apex acute to subacuminate, base $1.8-2.2 \mathrm{~mm}$ wide, inner surface glabrous, outer surface $60 \%$ covered in a mixture of dimorphic stellate hairs (Fig. 1K): 1) 5 - 7-armed hairs $0.15-0.2 \mathrm{~mm}$ diam. 2) 6-9-armed hairs $0.4-0.7 \mathrm{~mm}$ diam. Stamens 5, alternating with carpels, each $1 \mathrm{~mm}$ long, indehiscent. Gynoecium: ovary $4-5$-lobed, $1.75 \times$ $3.2 \mathrm{~mm}$, densely patent hairy, style c. $1 \times 1 \mathrm{~mm}$, densely patent hairy, hairs extending to the dorsal surfaces of the style-arms, hairs $0.2 \mathrm{~mm}$ long, patent. Style arms (4 -) 5, spreading, $3.5-4 \mathrm{~mm}$ diam., each blade-like laterally flattened $1.5 \times 0.6-0.7 \times 0.2-0.3 \mathrm{~mm}$, the apex recurved, the ventral edge lacerate. Fruit pedicels accrescent $1.5-$ $2.2 \mathrm{~cm}$ long, articulation $0.4-0.6 \mathrm{~cm}$ below the apex; perianth persistent; carpels (1 -) $4(-5)$, each globose $1-$ $1.5 \mathrm{~cm}$ diam., apex rounded, base stipitate, stipe slender 2 $-3 \mathrm{~mm}$ long; orange, with a slight ventral groove, stigmas persistent, indumentum of scattered 5 - 9-armed stellate hairs, each $0.4-0.7 \mathrm{~mm}$ across. Fig. 1

RECOGNITION. Differing from Cola greenwayi in that leafblades $(1.2-) 3.5-8.5(-10.4) \mathrm{cm}$ long on a single stem, petioles $0.2-2(-3.7) \mathrm{cm}$ long, (not $3-16$ ( 18) $\mathrm{cm}$ long and $0.3-4(-5.6) \mathrm{cm}$ long respectively), flowers single per node (not in fascicles); fruitlet apex rounded, positioned apically, base stipitate (not rostrate, lateral and obtuse to acute).

DISTRIBUTION. South Africa: KwaZulu Natal (Map 1).

SPECIMENS EXAMINED. SOUTH AFRICA. KwaZulu-Natal, uMkhanyakude Distr. (specimens grouped according to the 1:50 000 quarter-degree mapping grid used in South Africa). 2632CC. Tembe Elephant Park, Western Boundary in corridor area, 28 Oct. 1993, P. van Wyk BSA1312 (PRE); ibid., Tembi, male fl., 17 Jan. 1999, Schmidt 2111 (BRNH! image); Ulukondo Ndumu Game Reserve, Ingwavuma Distr., male fl., 26 Oct. 1970, Pooley 867 (K!, NU); Ndumu Game Reserve, st., 21 Nov. 1967, Strey E Moll 3757 (K! PRE); Ndumu Game Reserve, Khondo Sand Forest, March 1968, de Moor 34 (PRE); ibid., 17 Oct. 1968, Garland S301, 302, 303, 304, 305, 306 (all PRE); ibid., Oct. 1968, Garland 47574 (PRE); ibid., 19 Jan. 1968, Garland 47576 (PRE). 2632DC. Manguzi, Mabibi-Bos, wes van Manguzi, 3 Oct. 1984, D. J. Botha 3485 (PRE). 2732AB. 10 miles Pongola Bridge/Maputa, Ubombo, female fl., 8 Nov. 1969, Moll (4388 (K!; NH; PRE); Ingwavuma Distr., 1 mile E of Makane's Drift, female fl., 22 Nov 1967, Moll Ẽ Strey 3773 (K!, PRE); ibid., 1 mile E of Pongola Pont, 23 Nov. 1967, Strey E Moll 3774 (PRE); ibid., E of Pongola R., Jan. 1968, Garland 47580 (PRE); ibid., 2 km E of Makane's Drift, 30 May 1972, Stephen 733 (PRE); Makane's Pont; Pongola R., 10 Nov. 1983, Poynton PRF17953 (PRE); Mengu, Pongola R., Makane's Pont near Jobe's Kraal, 13 Oct. 1969, Garland 434 (PRE); E of Pongola R., Jan. 1968, Garland 47565 (PRE); E side of Pongola R., Ndumo sandveld, road Ndumo-Jozini, 30 


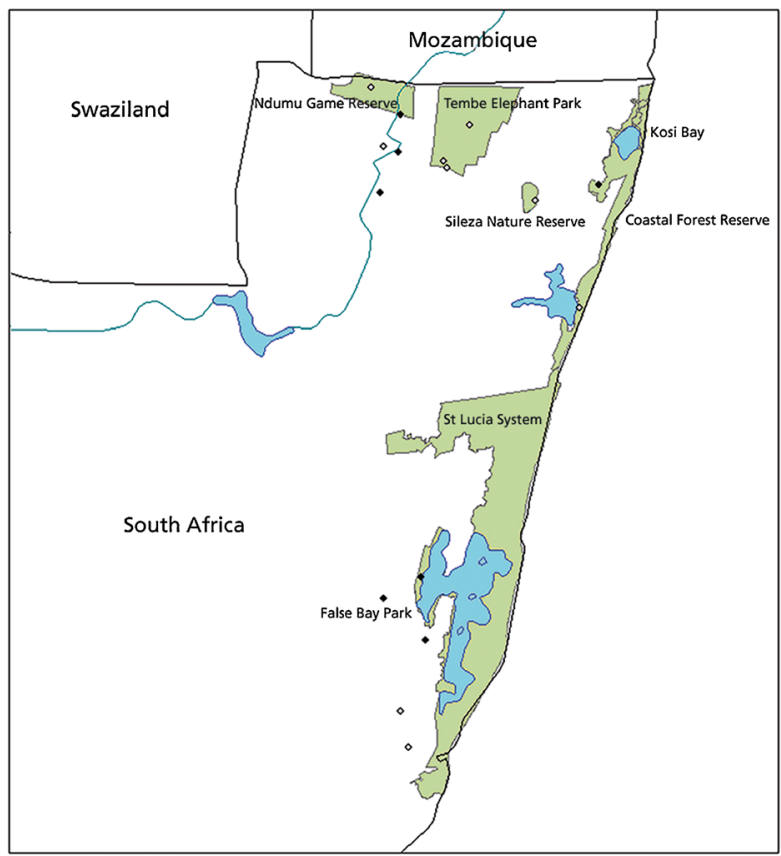

Map 1. Global distribution of Cola dorrii. Grey diamonds indicate specimens that have been seen, black diamonds specimens that have not been verified (unseen). Green areas are formally protected. DESIGNED BY POPPY LAWRENCE.

Oct. 1993, P. van Wyk 1342 (PRE); Makanes Pont; Mengwu Sand Forest, 13 Nov. 1968, H. J. T. Venter 5153 (PRE); nr Sihangwane Store, fr., 25 Jan. 1964, Tinley 883 (K!, NU); Sihangwana, 24 Feb. 1982, Retief 803 (PRE). 2732BA. $50 \mathrm{~km}$ from Mbazwana to Kosi Bay, 28 Jan. 1967, Schuhardt DSO1021 (PRE). 2732BC. Ubombo Distr. 2732BC (Ubombo) Mondozi Lake Forest, Lake Sibayi, male fl., 13 Feb. 1976, Brenan 14225(K!); ibid., Lake Sibayi, st., 29 March 1965, Vahrmeijer 720 (K!, PRE); ibid., 14 Sept. 1965, Vahrmeijer 1080 (PRE); E Shores of Lake Sibayi on old rd, 12 Sept. 1971, Stephens 381 (PRE); Lake Sibayi, Ubombo, fl. buds, Oct. 1968, Garland s.n. (K!, NH); Lake Sibayi, 16 Sept. 1971, Stephens 411 (PRE); at Mandozi, on E Shore Lake Sibayi Mbazwana, 24 Oct. 1966, De Winter 8524 (PRE); Lake Sibayi, Drum Island Forest, 26 Oct. 1994, Lubbe 383 (PRE). 2732CD. Hlabisa Distr., False Bay, 16 Jan. 1968, Garland 26 (PRE); False Bay Park, Mpophomeni Trail, 27 Jan. 1981, Ankiewicz 10 (PRE); False Bay Park, 28 Jan. 1967, Strey 7342 (PRE); ibid., Nov. 1967, Garland 47563 (PRE); ibid., 12 Jan. 1968, Garland 47575 (PRE); ibid., False Bay, Bird Sanctuary Bushveld Reserve, Near Mr Redman's Camp, 27 June 1944, Gerstener 4757 (PRE); ibid., 17 Feb. 1986, Venter 11509 (PRE); ibid., 9 July 1961, Ward 3664 (PRE); ibid., Ward 3676 (PRE). 2832AB. Charter's Creek E of Ndhlozi pan, 11 Oct. 1958, Rochet 14 (PRE); ibid., Rochet 15 (PRE). 2832AD. Dukuduku forest, fr., 23 Nov. 1964, Strey 5593 (K!, PRE); ibid., Dukuduku Forest, st., 1934, F.D. Herb 8676, Forester 52 (K!, PRE).

HABITAT. Sand Forest and Northern Coastal Forest; 5 $150 \mathrm{~m}$ asl.
CONSERVATION STATUS. Cola dorrii has not been previously assessed for its conservation status, since it was formerly included within a broadly delimited C. greenwayii var. greenwayii. The latter taxon was treated as Least Concern by Foden \& Potter (2005) accessed at http:/ / redlist.sanbi.org/genus.php?genus=1854. and by Raimondo et al. (2009). This was because of the very large extent of occurrence of that taxon as previously delimited by authors such as Verdoorn (1981).

As delimited in this paper, and using the georeferenced specimens cited above, Cola dorrii has an EOO of $4787 \mathrm{~km}^{2}$ and an AOO of $72 \mathrm{~km}^{2}$. This was calculated using Geocat (Bachman et al. 2011) set to the IUCN preferred cell size of $4 \mathrm{~km}^{2}$.

Cola dorrii currently appears to survive at nine locations, most of which are designated as protected but at which it is threatened. These, with threats are as follows, listed from north to south:

1. Tembe Elephant Park (TEP) where sand forests are threatened by trampling and browsing by unsustainably high elephant populations (Stone \& Ntetha 2013; Potgieter 2013).

2. Ndumo Game Reserve. The sand forest habitat in Ndumo is threatened by land invasions from surrounding communities seeking arable land for cultivation.

3. The site on the road between Mbazwana and Kosi Bay (Schuhardt DSO1021), inside or on the boundary of Kosi Bay protected area. Here the sand forest has been heavily impacted by subsistence agriculture. So we could consider this a site that potentially still has the species but is significantly threatened by further habitat loss.

4. Sileza Nature Reserve. This appears to be well protected.

5. Lake Sibayi (also known as Sibhayi and Sibaya). All sites appear to be within the protected area between lake and coast and to be well-protected.

6. False Bay Park section of iSimangaliso Wetland Park. The forest habitat for the species at this location appears well-protected.

7 - 9. Dukuduku Forest, Mtubatuba, and Hluhluwe. Such forests are threatened by habitat alteration through the invasion of the alien shrub Chromolaena odorata (L.) R. H. King \& H. Rob. and habitat loss through informal settlement (Ntombela 2003).

At four locations Cola dorrii appears likely to have been lost altogether due to habitat loss (W. McCleland pers. comm. 2017; observations on Google Earth). These are at Charter's Creek, and at three locations along the Pongola River at Makane's Drift. Most of the habitat in the vicinity of the drift has been transformed through subsistence agriculture (up to at least $3 \mathrm{~km}$ east of the drift, which is the area that Moll $\mathcal{E}^{\circ}$ Strey 3773, Moll E Strey 3774, Stephen 733, Poynton 
PRF17953 and Garland 434 were collected in: W. McCleland pers. comm. 2017).

As a consequence, gaps have widened in the distribution. So, between the southernmost locations (Mtubatuba and Dukuduku forest), and the next extant locations to the North, at Hluhlwe and False Bay, a gap has opened up due to apparent loss of habitat at Charter's Creek.

A further gap of $80 \mathrm{~km}$ occurs between False Bay and Lake Sibayi, locations. However, we consider this is insufficient to rate as severely fragmented due to habitat loss. Equally, although four of the former 13 locations have been lost, equating to a $30 \%$ loss over the last 50 years since the specimens evidencing these locations were collected, we consider this too unreliable to invoke Criterion A.

Instead we here assess Cola dorrii as Vulnerable VU $\mathrm{B} 1+\mathrm{B} 2 \mathrm{ab}(\mathrm{i}-\mathrm{v})$ since we count nine locations where Cola dorrii it is still extant, most of which are in formal protected areas, yet at six of which it is threatened as documented above.

At Lake Sibayi, some sites were not traced with certainty and were considered as possibly being outside of the protected area, these being Drum Island and Mondozi (or Mandozi) Forest. Neither of these appear on old topographical maps. However, Mandozi is indicated as being on the eastern lake shore, so would therefore be in the protected part of the forest. A lookout point near the south-eastern part of the lake is called "Dumile" which means "to thunder or drum", so we assume that Drum Island may refer to this, which would also place it in the eastern part of the lake and in protected forest.

It is possible that this species may yet be found at additional locations. There is a near-continuous strip of coastal forest from Lake Sibayi to Bhanga Nek (about $22 \mathrm{~km}$ long) and much coastal forest between Cape Vidal and Sodwana Bay (about $45 \mathrm{~km}$ of coastline) that has not been intensively floristically studied but which resembles the Lake Sibayi forest. The gap along the coast between Dukuduku and Lake Sibayi may be more a function of undersampling than true fragmentation.

ETYMOLOGY. named for Dr Laurence ('Larry') Dorr (1953 -) who with the first author wrote the Sterculiaceae account for Flora of Tropical East Africa in which this species was first mooted as distinct (Cheek \& Dorr 2007). A leading specialist in Malvales globally and with floristic expertise in Madagascar, Africa and the New World, Dr Dorr is Chair of the Botany Department, Smithsonian Insitution (US), USA, having previously initiated Missouri Botanical Garden's (MO) research and exploration programme in Madagascar (1983 - 1986) before conducting floristic survey work in the Andes of $\mathrm{S}$ America for New York Botanical Garden (NY) in the Bronx (1988 - 1991).
LOCAL NAMES. Hairy Cola (English); Harige Kola (Afrikaans) (Boon 2010); Baster knoppel-hout (Afrikaans) (Moll 1981); Umqhosho, Umthenenende, Intandothi (isiZulu) (Boon 2010); Mqobo (Forester 52, K) Zulu; Umbidzane (siSwati) (Loffler \& Loffler 2005) LOCAL USES. "fruit sometimes chewed by the Zulus, but never swallowed. They are eaten by Livingstone's antelope (Suni), Red Duiker, and rodents. Zulus use the tree medicinally. They value it most for its wood which - together with that of Cola natalensis - makes the best of all sticks (hence the name Umqhosho, meaning "the Vanquisher"). It is also used for upright house poles." (Palmer \& Pitman 1972: 1491; Boon 2010: 354).

\section{The ecology \& distribution of Cola dorrii}

Cola dorrii is endemic to the Maputaland coastal plain in northern KwaZulu-Natal, South Africa (Map 1). It has not yet been discovered over the border in southern Mozambique despite being found at the border fence in South Africa, so its presence in Mozambique is to be expected so long as suitable habitat remains intact there. Cola dorrii occurs in two distinctly different forest types, namely Sand Forest and Northern Coastal Forest (Mucina \& Rutherford 2006). Sand Forest is described by Pooley (1993: 16) as being restricted to deep sands on inland fossil dunes that define a former coastline. This forest type occurs in a fragmented belt from 12 to $55 \mathrm{~km}$ inland and extends over $200 \mathrm{~km}$ in length from the False Bay Park section of the iSimangaliso Wetland Park in the south to the Licuati Forest in southern Mozambique in the north. It is present in a number of formal conservation areas, most notably Tembe Elephant Park (TEP). Matthews et al. (2001) described eight vegetation communities in TEP, one of which refers to Sand Forest, namely the Drypetes arguta - Uvaria lucida community. Two subcommunities were recognised, the first of which is "Cola greenwayi - Balanites maughamii tall Sand Forest", in which the "diagnostic consistent species are the tall tree Balanites maughamii and the understory shrub Cola greenwayii." This subcommunity is associated with dune slopes and depressions on orange brown arenosols and dystric regosols (largely sands with very little clay) at $\mathrm{pH}$ 5.6. Cola greenwayi (i.e. C. dorrii) is recorded as being almost entirely restricted to this subcommunity within the eight Maputaland communities at TEP (Matthews et al. 2001).

Northern Coastal Forest, as described by Mucina \& Rutherford (2006), formerly referred to under other names, such as "Coastal Tropical Forest" or "coastal dune forest" (Breen 1971), occurs along the South African coastline from the Eastern Cape to the border with Mozambique and extralimitally along the entire Mozambique seaboard to southern Tanzania. It differs 
significantly from Sand Forest in being confined to deep sands on relatively recent (younger than 10,000 years) coastal dunes, and in having a different suite of dominant tree and shrub species, such as Mimusops caffra, Diospyros natalensis, Sideroxylon inerme and Psydrax obovata. A number of Cola dorrii specimens have been collected historically from Northern Coastal Forest, specifically in the vicinity of Lake Sibayi, Manguzi and Dukuduku Forest. Breen (1971) gave an account of the Northern Coastal ("Dune Forest") at Sibayi. Cola dorrii (as C. natalensis) is one of 86 tree species recorded, and is one of the species occurring at median frequency, at a relative density of 0.6 . It is not one of the major components of the canopy. Of the five stems recorded in Breen's enumeration of this species, two were $7.5 \mathrm{~cm}$ girth class, one in the $10 \mathrm{~cm}$, and two in the $15 \mathrm{~cm}$ girth classes, these individuals all occurring in the 3-6 m height class apart from one in the $2.1-3 \mathrm{~m}$ height class. Most canopy individuals of this forest type occur in the the $3-6 \mathrm{~m}$ height class, with the highest canopy trees being in a class above 9 $m$ high. Breen (1971) estimates that the annual rainfall of Sibayi is in the order of $1000 \mathrm{~mm}$, falling mostly between September and May.

Maputaland (formerly Tongaland), extending from Kwazulu Natal into southern Mozambique, is considered a regional centre of endemism with at least 230 species and infraspecific taxa of plant documented as being endemic or near endemic (van Wyk 1996). Of these, at least 27 are restricted to Sand Forest (known as Licuati Forest in Mozambique) (Matthews et al. 2001).

A similar case of a species recently discovered to be endemic to the Sand Forest of Maputaland is that of Warneckea parvifolia R. D. Stone \& Ntetha which had previously also been considered conspecific with a species to the north in tropical Africa, and which like Cola dorrii has smaller leaves in comparison with those relatives (Stone \& Ntetha 2013).

In several parts of tropical Africa and Madagascar, areas of sand, usually coastal, and derived from ancient-dunes have unique assemblages of species including narrowly endemic species and even genera. Examples occur in coastal Cabinda to Gabon (Cheek et al. 2014; Gosline et al. 2014); in coastal northern Mozambique (Timberlake et al. 2011 and Johnson et al. 2017) and in North West Madagascar (Stirton \& DuPuy 1992).

PHENOLOGY. Flowering occurs in Oct. - Nov., after the rains begin in September, in the southern spring, with out-of-season flowers as late as February (Brenan 14225). Fruits follow in Nov. - Feb. In March - April new shoots and leaves are produced in a flush, after which during the dry season, growth appears to cease until October, during which time axillary inflorescence buds develop, while the dormant stem apex is covered by bud-scales. Leaves persist on the stems for at least 3 seasons.
STEM ARCHITECTURE. The first leaves of the season's stem growth in March are the largest, with the longest petioles, to $20(-37) \mathrm{mm}$ long. A season's growth can be $4 \mathrm{~cm}$ to $8.5 \mathrm{~cm}$ long, with (3-) 5 to 12 leaves. The last leaves of the flush are progressively smaller, with shorter petioles only $2-3 \mathrm{~mm}$ long, so that the leafy stem resembles a tiled dome, lacking light gaps.

Stems in the first season are covered in stellate hairs, conspicuously so in the first and second internodes when large but caducous pale brown sinuous-armed stellate hairs are present. These soon fall, but more numerous, denser and less conspicuous translucent-white, appressed armed minute stellate hairs persist. In the second season the stems are largely free of hairs, with white epidermis, with shallow longitudinal grooves.

DIOECY. The sexuality of Cola species has been given as "Dioecious or monoecious, occasionally with bisexual flowers" (Verdoorn 1981). However, in the case of Cola dorrii, all the evidence currently available indicates that the species is dioecious. Of the ten specimens cited in this paper, those in flower had either all male flowers, or all female flowers. One specimen (Moll 4388, K) has notes stating clearly: "female flowers only found on the tree" and another Moll E Strey 3773 "dioecious".

While female flowers were observed always to have full-sized anthers, these were never seen to be dehisced, so that functionally the stamens in female flowers appear to be sterile.

Schmidt 3434 (BRNH image!), a fruiting specimen that fits Cola dorrii, is atypical in its geography since it occurs further inland than all other verified specimens of $C$. dorrii and not in the coastal forest or sand forest to which $C$. dorrii seems otherwise restricted. If this specimen is not the product of a labelling error, it means that the range of the species may be larger than current data suggests, and may extend to the Lubombo Mts of Swaziland to which it is known that some sand forest species extend, and whence records of "Cola greenwayii" have been made but not been seen by us (W. McCleland pers. comm. Nov. 2017). Further investigation is planned to address this question.

\section{The Barberton Cola}

Verdoorn (1981) refers to the surprising discovery of Cola in the Barberton Distict of Transvaal, now Mpumulanga. She included these specimens in her broad concept of $C$. greenwayi var. greenwayi. The specimens seen from this upland area differ greatly in multiple leaf characters from those of $C$. dorrii. In this respect they indeed fit best with $C$. greenway $i$ var. greenwayi as defined in Table 1. Thus South Africa now certainly has three species of Cola, not two. 


\section{Acknowledgements}

The boost to reawaken the monographic study of Cola was provided by sponsorship via IUCN from the Toyota Motor Corporation to the RBG, Kew conservation assessment unit to increase assessment output of plant species. This resulted in support by Eimear Nic Lughadha and Serene Hargreaves for an internship specifically to assess the conservation status of Cola species (Poppy Lawrence), necessitating renewed work on species delimitation of that genus by the first author to support these. Barbara Turpin at BNRH kindly provided scans of all specimens of Cola at her herbarium. Janis Shillito is thanked for typing the manuscript and two anonymous reviewers for valuable comments on an earlier version of this paper.

Open Access This article is distributed under the terms of the Creative Commons Attribution 4.0 International License (http://creativecommons.org/ licenses/by/4.0/), which permits unrestricted use, distribution, and reproduction in any medium, provided you give appropriate credit to the original author(s) and the source, provide a link to the Creative Commons license, and indicate if changes were made.

\section{References}

Bachman, S., Moat, J., Hill, A., de la Torre, J. \& Scott, B. (2011). Supporting Red List threat assessments with GeoCAT: geospatial conservation assessment tool. ZooKeys 150: 117 - 126. https://doi.org/ 10.3897/zookeys.150.2109

Baum, D. A., Alverson, W. S. \& Nyffeler, R. A. (1998). A durian by any other name: taxonomy and nomenclature of the core Malvales. Harvard Pap. Bot. 3: 315 - 330 .

Bayer, C., Fay, M. F., De Bruijn, A. Y., Savolainen, V., Morton, C. M., Kubitzki, K., Alverson, W. S. \& Chase, M. W. (1999). Support for an expanded family concept of Malvaceae within a recircumscribed order Malvales: a combined analysis of plastid atpB and rbcL DNA sequences. Bot. J. Linn. Soc. 129: 267 - 303.

\& Kubitzki, K. (2003). Malvaceae. In: K. Kubitzki

\& C. Bayer (eds), The families and genera of vascular plants 5: flowering plants dicotyledons. 225 - 311. Springer-Verlag, Berlin.

Boon, R. (2010). Pooley's Trees of Eastern Southern Africa. $2^{\text {nd }}$ Ed. Flora and Fauna Publications Trust, Durban.

Breen, C. M. (1971). An account of the plant ecology of the dune forest at Lake Sibayi. Trans. Roy. Soc. South Africa 39 (3): 223 - 234.

Brenan, J. P. M. (1956). The Genus Cola in Kenya, Uganda and Tanganyika. Kew Bull. 11: 141 - 152. \& Keay, R. W. J. (1955). Hooker's Icon. Pl. t. 3529 - 3537.
Cheek, M. (2002a). Three new species of Cola (Sterculiaceae) from western Cameroon. Kew Bull. 57: 402 - 415. https://doi.org/10.2307/4111117 (2002b). A new species of Cola (Sterculiaceae) from the Usambara Mts, Tanzania. Kew Bull. 57: 417 - 422. (2007a). Bombacaceae. In: V. H. Heywood, R. K. Brummitt, A. Culham, A. \& O. Seberg (eds), Flowering plant families of the world, pp. 65. Royal Botanic Gardens, Kew.

(2007b). Brownlowiaceae. In: V. H. Heywood, R.

K. Brummitt, A. Culham, A. \& O. Seberg (eds), Flowering plant families of the world, pp. 71. Royal Botanic Gardens, Kew.

(2007c). Byttneriaceae. In: V. H. Heywood, R. K. Brummitt, A. Culham, A. \& O. Seberg (eds), Flowering plant families of the world, pp. 76. Royal Botanic Gardens, Kew.

(2007d). Durionaceae. In: V. H. Heywood, R. K. Brummitt, A. Culham, A. \& O. Seberg (eds), Flowering plant families of the world, pp. 134. Royal Botanic Gardens, Kew.

(2007e). Helicteraceae. In: V. H. Heywood, R. K. Brummitt, A. Culham, A. \& O. Seberg (eds), Flowering plant families of the world, pp. 165. Royal Botanic Gardens, Kew.

(2007f). Malvaceae. In: V. H. Heywood, R. K. Brummitt, A. Culham, A. \& O. Seberg (eds), Flowering plant families of the world, pp. 201 - 202. Royal Botanic Gardens, Kew.

(2007g). Pentapetaceae. In: V. H. Heywood, R. K. Brummitt, A. Culham, A. \& O. Seberg (eds), Flowering plant families of the world, pp. 247 - 248. Royal Botanic Gardens, Kew.

(2007h). Sparrmanniaceae. In: V. H. Heywood, R. K. Brummitt, A. Culham, A. \& O. Seberg (eds), Flowering plant families of the world, pp. $307-308$. Royal Botanic Gardens, Kew.

(2007i) Sterculiaceae. In: V. H. Heywood, R. K. Brummitt, A. Culham, A. \& O. Seberg (eds), Flowering plant families of the world, pp. 311 - 312. Royal Botanic Gardens, Kew.

(2007j). Tiliaceae. In: V. H. Heywood, R. K. Brummitt, A. Culham, A. \& O. Seberg (eds), Flowering plant families of the world, pp. 321 - 322. Royal Botanic Gardens, Kew.

\& Dorr, L. (2007). Sterculiaceae. In: H. J. Beentje \& S. A. Ghazanfar (eds), Flora of Tropical East Africa, pp. 133. Royal Botanic Gardens, Kew. Kami, E. \& Kami, T. (2014). Baphia vili sp. nov. (Leguminosae-Papilionoideae) of coastal thicket of the Congo Republic and Gabon. Willdenowia 44: 39 44. https://doi.org/10.3372/wi.44.44106

Coates Palgrave, K. G. (1977). Trees of Southern Africa. Struik, Capetown.

Drummond, R. (1975). A list of trees, shrubs and woody climbers in Rhodesia. Kirkia 10: 229 - 285. 
ESRI ArcWorld Database [computer file] (1992). Environmental Systems Research Institute, Redlands, California.

Foden, W. \& Potter, L. (2005). Cola greenwayi Brenan var. greenwayi. National Assessment: Red List of South African Plants. http://redlist.sanbi.org/ species.php?species=1854-1 (accessed 31/10/2017).

Germain, R. (1963). Cola. In: Flore du Congo, Rwanda et $d u$ Burundi Vol. 10, Sterculiaceae, pp. 277 - 316. Institut national pour l'etude agronomique du Congo belge, Bruxelles.

Gosline, G., Cheek, M. \& Kami, T. (2014). Two new African species of Salacia (Salacioideae, Celastraceae). Blumea 59: 26 - 32.

Hallé, N. (1961). Cola (Sterculiaceae). In: A. Aubréville, Flore du Gabon 2: 38 - 104. Muséum national d'histoire naturelle, Paris.

IPNI (continuously updated). The International Plant Names Index. http://ipni.org/. (accessed: 01/2017).

IUCN (2012). IUCN Red List Categories and Criteria: version 3.1. Second edition. Gland and Cambridge. http:// www.iucnredlist.org/ (accessed: 01/2017).

Johnson, D. M., Luke, Q., Goyder, D. J. \& Murray, N. A. (2017). Four new species of Xylopia (Annonaceae) from East Africa. Kew Bull. 72 (11): 1 - 13. https://doi.org/10.1007/S12225-017-9681-X

Keay, R. W. J. \& Brenan, J. P. M. (1958). Cola In: R. W. J. Keay (ed.), Flora of West Tropical Africa 1: 321 332. Crown Agents, London.

Loffler, L. \& Loffler, P. (2005). Swaziland Tree Atlas. Southern African Botanical Diversity Network Report No. 35. Sabonet, Pretoria.

Matthews, W. S., Van Wyk, A. E., van Rooyen, N. \& Botha, G. A. (2001). Vegetation of the Tembe Elephant Park, Maputaland, South Africa. S. African J. Bot. 67: 573 - 594.

Moll, E. (1981). Trees of Natal. University of Cape Town.

Mucina, L. \& Rutherford, M. C. (eds) (2006). The Vegetation of South Africa, Lesotho and Swaziland. Strelitzia 19. South African National Biodiversity Institute, Pretoria.

Ntombela, T. E. (2003). The impact of subsistence farming and informal settlement on Dukuduku Forest as a tourist resource. MA Dissertation, University of Zululand, Durban-Umlazi Campus.

Oliver, D. (1882). Cola natalensis. Hooker's Icon. Pl. 14: 70 , t. 1390.

Onana, J-M. \& Cheek, M. (2011). Red Data Book of the flowering plants of Cameroon: IUCN global assessments. Royal Botanic Gardens, Kew.

Palmer, E. \& Pitman, N. (1972). Trees of Southern Africa Vol. 2. A. A. Balkema, Cape Town.

Pooley, E. (1993). Field guide to the trees of Natal, Zululand and Transkei. Natal Flora Publications Trust, Durban.

Potgieter, M. (2013). Long-term monitoring of elephant impact on the woody vegetation in the Tembe Elephant
Park, South Africa. MSc Dissertation, University of Pretoria, Pretoria.

Raimondo, D., von Staden, L., Foden, W., Victor, J. E., Helme, N. A., Turner, R. C., Kamundi, D. A. \& Manyama, P. A. (2009). Red List of South African Plants. Strelitzia 25. South African National Biodiversity Institute, Pretoria.

Schumann, K. (1900). Sterculiaceae Africanae. In: A. Engler, Monographien afrikanischer PflanzenFamilien und -Gattungen. Wilhelm Engelmann, Leipzig.

Stirton, C. H. \& DuPuy, D. J. (1992). A new species of Baphia (Leguminosae: Papilionoideae) from Madagascar. Kew Bull. 47: 289.

Stone, R. D. \& Ntetha, N. A. (2013). Warneckea parvifolia (Melastomataceae-Olisbeoideae), a new "sand-forest" endemic from northeastern KwaZulu-Natal (South Africa) and southernmost Mozambique, and a phylogenetic analysis of eastern and southern African representatives of Warneckea section Warneckea. S. African J. Bot. 88: 317 - 325.

Thiers, B. (continuously updated). Index Herbariorum: A global directory of public herbaria and associated staff. New York Botanical Garden's Virtual Herbarium. http:// sweetgum.nybg.org/ih/ (accessed: 01/2017).

Timberlake, J., Goyder, D., Crawford, F., Burrows, J., Clarke, G. P., Luke, Q., Matimele, H., Müller, T., Pascal, O., de Sousa, C. \& Alves, T. (2011). Coastal dry forests in northern Mozambique. Pl. Ecol. Evol. 144: 126 - 137.

UNEP-WCMC (2017). The World Database on Protected Areas (WDPA) [On-line], November 2017 (version 3.1). UNEP-WCMC, Cambridge. Available at: www.protectedplanet.net

Van Wyk, A. E. (1996). Biodiversity of the Maputaland Centre. In: L. J. G. Van der Maesen, X. M. Van der Burgt \& J. M. Van Medebach de Rooy (eds), The Biodiversity of African Plants, pp. 198 - 207. Kluwer Academic Publishers, Dordrecht.

Van Wyk, B. \& van Wyk, P. (2013). Field Guide to the Trees of Southern Africa. $2^{\text {nd }}$ Ed. Struik Nature, Capetown.

Verdoorn, I. C. (1981). The genus Cola in Southern Africa. Bothalia 13: 277 - 279.

Wild, H. (1961). Sterculiaceae. In: Flora Zambesiaca 1: 517 - 564. Published on behalf of the Governments of Portugal, the Federation of Rhodesia and Nyasaland, and the United Kingdom by the Crown Agents for Oversea Governments and Administrations, London.

Wilkie, P., Clark, A., Pennington, R. T., Cheek, M., Bayer, C. \& Wilcock, C. C. (2006). Phylogenetic Relationships within the subfamily Sterculioideae (Malvaceae/Sterculiaceae-Sterculieae) using the chloroplast gene ndhF. Syst. Bot. 31: $160-170$. 